\title{
Global Public Health Security: Three Vital Lessons
}

\author{
Yuanli Liu
}

\begin{abstract}
Public health and its management have come into very sharp focus due to COVID-19. In this analysis the writer suggests that the COVID-19 pandemic has taught the world both the vulnerability and power of the human community. The power is symbolised by the creation of vaccines in a fraction of the time that was the norm before 2020. This essay also describes three major lessons that may have important implications for better protecting global public health security today and tomorrow. Any open-minded analysis, and serious reflection, on the world's responses to COVID-19 should draw these vital conclusions. In order for the world to stand a better chance of preventing the next public health emergency, such as a new pandemic, all nations must learn how to work together and in the most effective manner. This must include important issues such as reforms of international health regulations and updating of international organisational structures. It also means we must learn how to strengthen (not weaken) multilateral mechanisms such as the $U N$ and the WHO. Of course, any new cooperative spirit must be built on the keen recognition that we are really in this together. That realisation must be extended to how mankind interacts with all-natural life in our shared home-the Earth.
\end{abstract}

Keywords The vulnerability and power of the human communities $\cdot$ Creation of vaccines in a fraction of the time $\cdot$ Global public health security $\cdot$ Reforms of international health regulations - Updating of international organisational structures - Strengthen (not weaken) multilateral mechanisms such as the UN and the WHO $\cdot$ How mankind interacts with all-natural life

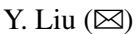

School of Health Policy and Management, Peking Union Medical College, Beijing, China

(C) The Author(s) 2021

H. Wang and A. Michie (eds.), Consensus or Conflict?, China and Globalization, https://doi.org/10.1007/978-981-16-5391-9_13
} 


\section{Mankind's Power and Vulnerability}

COVID-19 provides a unique collective learning opportunity for all mankind about global public health security. History may very well remember COVID-19 as the pandemic of the twenty-first century.

The spread of viruses does not respect national boundaries and, in a pandemic, no nation is safe until everyone is safe. Therefore, by its very nature, dealing with infectious diseases is always a global issue. In other words, actions or inaction by any one country in a pandemic is bound to have global consequences. In turn, responses to a pandemic by nations in public health terms will have impacts across a range of issues. The bigger the country's relative role in world affairs, the bigger the consequences to international trade.

Moreover, like any other global issue, such as climate change, resolving global public health security issues requires integrated global action. Before wellcoordinated global action can be achieved, important issues need to be grasped and a fundamental consensus needs to be built.

As of early 2021, and 12 months since the outbreak of COVID-19, this public health crisis is far from being resolved and has yet to be brought under control in many parts of the world. But, in only one year this pandemic has taught us both how vulnerable and how powerful the human community has become. This essay tries to draw some major lessons that may have important implications for better protecting global public health security today and tomorrow.

\section{Lesson One: We Are Vulnerable}

Wuhan is my hometown. In early January 2020, I was making plans to join my ageing mother for the Chinese Lunar New Year. When this city of 11 million people was locked down on January 23, 2020, I, like many other people, felt uneasy and uncertain. Our concern revolved around thoughts about whether or not the lockdown policy was overkill. After all, descriptions of the illness causing the Wuhan lockdown sounded like a flu-like disease and the total number of confirmed cases amounted to only a little over 400. Nobody at the time, not in our wildest dreams, would have expected this novel disease would turn out to be such a vicious pandemic. The rapid spread of COVID-19 had a huge impact, disrupting the global economy at an unprecedented speed and scale and infecting over 123 million people globally, with a death toll of over 2.7 million and counting. ${ }^{1}$ This outcome certainly serves as vivid testimony to the existential threat posted by this novel virus to the whole human community.

The biosecurity issues caused by microbes, such as a virus, possess several important characteristics. First, a virus is not a threat to all life on a global scale. The reality is that the virus creates an inter-species war on the planet, which is a different threat than that posed by 'world wars' of the past. This is not a war that is fought over

\footnotetext{
${ }^{1}$ WHO Coronavirus (COVID-19) Dashboard (n.d.).
} 
national borders, but a battle in which all the countries of the world are faced with the same enemy.

Second, this threat is not a small probability event. Our world has witnessed an increasing number of novel infectious diseases in recent decades. ${ }^{2}$ There is compelling evidence that the increasing invasion of human activity into the natural world is connected to the rise of infectious diseases. The result is that animals, like bats, whose habitats had remained apart from humans for millennia, or even millions of years, now have direct contact with people. Viruses that have no effect on bats, or other species, have proven deadly when entering the bodies of humans. This trend provides a vital lesson in the vulnerability of mankind. When COVID-19 is finally over, which is possible with the rapid rollout of vaccination programmes around the world and the emergence of 'herd immunity', the world should, and must be, better prepared for the next novel infectious disease.

There is a big risk that global leaders may shy away from this need for vital preparation once there is 'herd immunity'. One reason for this is the natural human reaction to bury the pain of COVID-19 in the past. People will want messages of hope that promise a return to economic prosperity; they will not welcome messages that project fear of the threat of another pandemic and the need to prepare. This brings back memories of the challenge faced by President Roosevelt in the USA in 1933 when there was widespread fear about the continuous bouts of economic depression. As Roosevelt spelt out his plan for recovery he won support by saying it best- 'the only thing we have to fear is fear itself'. 3

\section{Lesson Two: We Are Powerful}

In his seminal book Social Conquest of the Earth, E.O. Wilson suggested that the fundamental factor affecting the chance of a particular species such as ants and humans to successfully survive and thrive lies in the capability to work together. ${ }^{4}$ It follows, then, we are powerful because humans are a collaborative bunch. Paradoxically, COVID-19 unveiled both the best and worst sides of human beings. As an example, let us compare the public health performance of the world's two largest economies (Fig. 1).

No nation in modern times has the experience of dealing with a disease like COVID-19, but despite being an inexperienced first responder, China managed to bring COVID-19 under control within two months after the outbreak. As of March

\footnotetext{
${ }^{2}$ Bloom and Cadarette (2019).

${ }^{3}$ World Affairs (1933).

${ }^{4}$ Liveright (2012).
} 
29, 2021, out of China's 1.4 billion people, there were 90,159 confirmed cases and 4,636 deaths. These numbers are in stark contrast to the data in the USA, which despite having a smaller population and bigger economy, has had far more deaths and infections (Fig. 1).

How can this happen and what are the underlying reasons for this paradox? Between 16th February 2020 and 24th February 2020 a survey was conducted in China by a WHO-China Joint Mission. It consisted of 25 national and international experts from China, Germany, Japan, Korea, Nigeria, Russia, Singapore, the USA and the World Health Organisation (WHO). The Joint Mission was headed by Dr. Bruce Aylward of the WHO and Dr. Liang Wannian of the People's Republic of China. In its published report, the Joint Mission described China's response to COVID-19 as consisting of three phases (see Fig. 2).

After the detection of a cluster of pneumonia cases of unknown aetiology in Wuhan, the Chinese government launched a national emergency response. Prevention and control measures were implemented rapidly in three main phases, with two important events defining those phases.

First, COVID-19 was included in the statutory report of Class B infectious diseases and border health quarantine infectious diseases on January 20, 2020. This marked the transition from the initial partial control approach to the comprehensive adoption of various control measures in accordance with the law.

\section{Worth noting: China is one of the few countries experiencing positive economic}

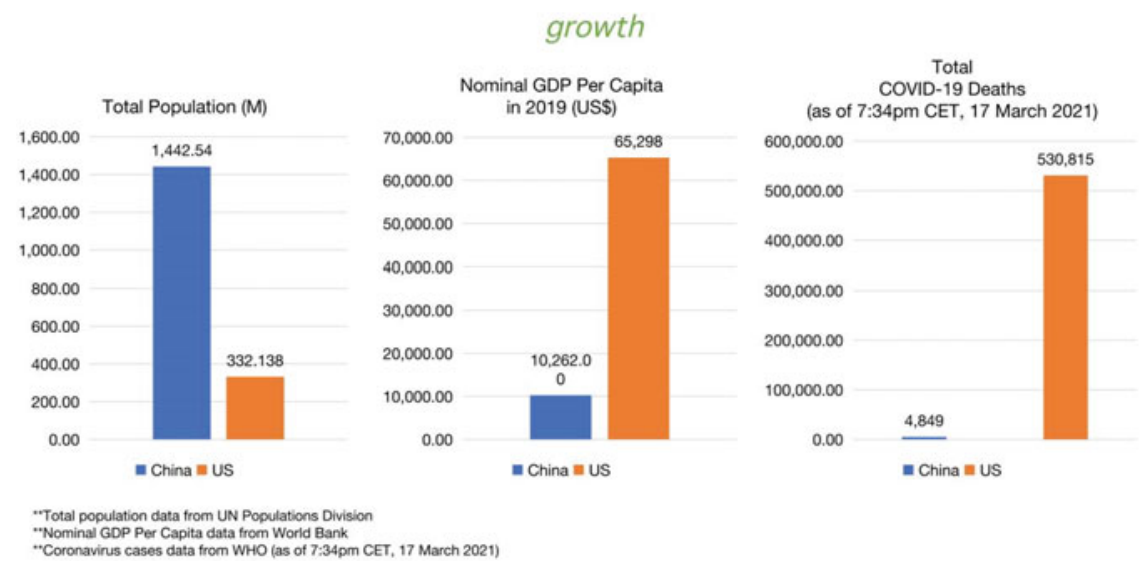

Fig. 1 The public health performance of the world's two largest economies during COVID-19 $9^{5,6,7}$

\footnotetext{
${ }^{5}$ WHO Coronavirus (COVID-19) Dashboard (n.d.).

${ }^{6}$ United Nations Population Division (n.d.).

${ }^{7}$ GDP per capita (current US\$) (n.d.).
} 
The second event was the State Council's issuing, on the 8th of February 2020, of 'The Notice on Orderly Resumption of Production and Resuming Production in Enterprises'. This indicated that China's national epidemic control work had entered a stage of general prevention and control together with the restoration of normal social and economic operations. The main reason why China was able to bring this public health crisis quickly under control was that China vigorously implemented traditional public health measures such as social distancing. This was the first key lesson China learned.

Traditional public health measures for controlling infectious diseases include isolation and quarantine, which are far easier said than done, especially at the early stage of an epidemic. On January 23, 2020, for the first time in the human history of epidemics, a mega city like Wuhan, with more than 11 million residents, was locked down. This lockdown was the most extreme form of social distancing in both scale and speed. When this unprecedentedly strict lockdown policy was implemented, many people started questioning the necessity of taking such an action because the number of confirmed cases in Wuhan, at the time of the lockdown was only a little over 400. In addition, the lockdown decision was taken prior to any scientific understanding of the transmissive power of this new virus. But the Wuhan lockdown turned out to be the most visionary and courageous decision in the fight against the COVID-19 pandemic, not only in China but also in the world at large. The fact is that Wuhan was the epicentre of COVID-19. If Wuhan, with its population of 11 million people, had not been locked down on January 23, 2020, it could have been the catalyst for

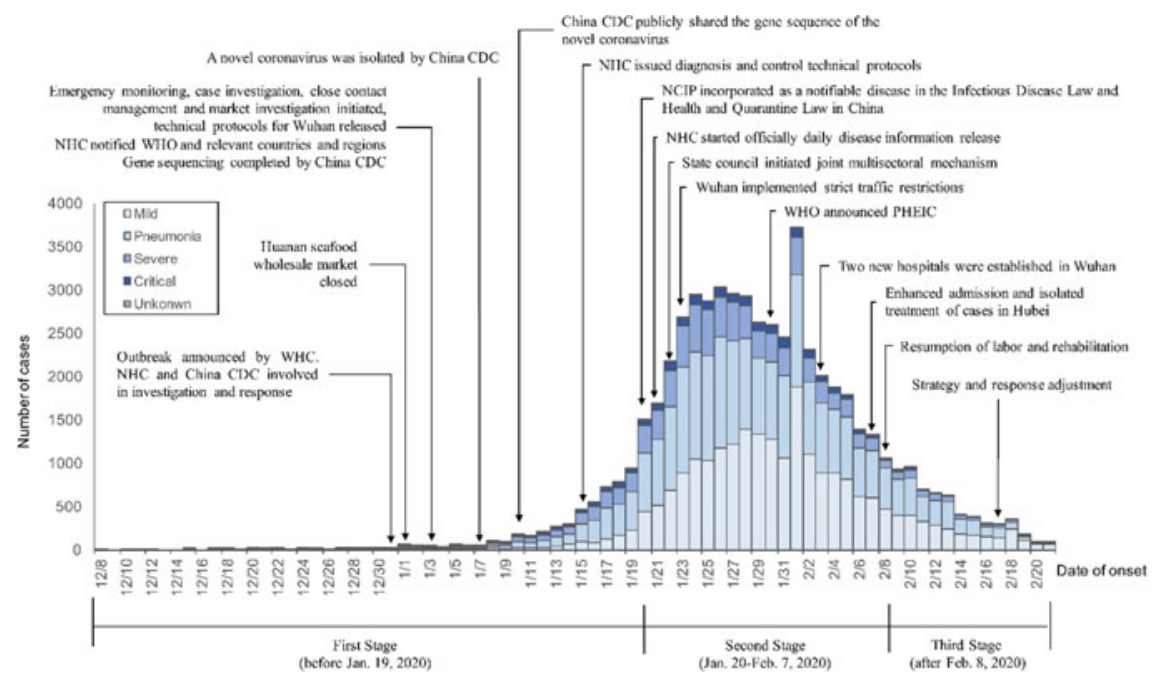

Fig. 2 Three phases of China's response to COVID-19 ${ }^{8}$

\footnotetext{
${ }^{8}$ World Health Organization (2020).
} 
a catastrophe. The reason for this is that January 24 was the day before the Chinese Lunar New Year holiday. In China, millions of people travel during this period to be reunited with their families. If Wuhan had not been locked down, the massive movement of people would have triggered a vast and rapid spread of the virus with disastrous consequences. Out of the total 90,000+ confirmed cases of COVID-19 in China, around $63 \%$ were found and treated in Wuhan.

According to research studies published in international peer-reviewed journals, the Wuhan lockdown helped avert millions of infections and hundreds of thousands of deaths. Based in part on data drawn from Wuhan, an Imperial College London Team published estimates of the impact of the lockdown in Wuhan. The analysis showed that a combination of home isolation of suspected cases, home quarantine of those living in the same household as people with suspected cases, and social distancing of the elderly and other high-risk groups may have reduced peak healthcare demand by two-thirds and deaths by half.

Looking back, the world owes Wuhan a debt of gratitude for its sacrifice during the lockdown. The cooperation of the 11 million residents of Wuhan and the thousands of people who rushed there to help greatly reduce the spread of COVID-19 in China and to the rest of the world. The people of Wuhan, and those that helped them get through this difficult time, made enormous sacrifices during the lockdown. But the greatest contribution was that it gave more time to other regions and countries to get ready. In turn, that offered the potential to minimise the global impact of COVID-19.

China also learned that solidarity is essential.

Infectious diseases do not respect geographic boundaries, and thus with any pandemic like COVID-19, we are all in this together. Helping others, especially the emerging epicentres of the crisis, is helping ourselves. Lessons also were learned in other nations. A characteristic of a virus like COVID-19 is that the outbreak comes in waves. In response to this pattern, the Governor of New York State, Andrew Cuomo, called for a rolling deployment strategy, ${ }^{9}$ which was exactly what China did, and it was done early and well. Soon after the lockdown in Wuhan, there was a rolling programme of vigorous testing and tracing. This was done by over 1,800 epidemic teams. They found that the number of confirmed cases in Wuhan increased rapidly, which quickly overwhelmed the local healthcare system. As a reaction to these trends, the Chinese government sent over 300 medical teams to Wuhan, including more than 42,000 doctors and nurses. In addition, 16 temporary hospitals were built within a matter of weeks. The objective was to admit all patients with mild symptoms and asymptomatic patients of COVID-19 so they would not spread the virus in their homes and communities. During the next stage, patients who became severely ill could then be quickly transferred to designated hospitals equipped with ICUs. When Wuhan was reopened on April 8, 2020, more than 60,000 patients had already been treated and recovered. This kind of achievement could not have been possible without a nationally coordinated strategy, national mobilisation of resources and aid that came from around China and abroad.

\footnotetext{
${ }^{9}$ Gov. Cuomo: Feds need to consider 'rolling deployment' focused on NY first (2020).
} 
Last but not the least, China, as well as other countries, learned a crucial lesson about the power of humanity during the COVID-19 pandemic and how science can help and save humanity.

When SARS hit China in 2002 it took more than two months to identify the pathogen. In 2020, with COVID-19, just two weeks after the central health authority in China was alerted, the novel coronavirus COVID-19 was identified by Chinese scientists. The information on the complete genetic sequence of the virus was shared with the world on January 10, 2020.

In addition to virology, new scientific knowledge and the power of technology is constantly being developed and implemented, including testing and tracing, treatment guidelines as well as in drugs and vaccines development. Scientists in different countries have developed COVID-19 vaccines at unprecedented speeds. This included scientists from the USA, China, the UK and Russia, and this scientific endeavour serves as another reminder of how powerful we as a human community can be if the best minds are put to work.

\section{Lesson Three: We Are Vulnerable Because We Are Powerful}

While China was engrossed fighting to stem the spread of the COVID-19 virus, the WHO sounded its highest alarm on January 30, 2020, declaring a 'public health emergency of international concern', or PHEIC. This alerted the world that a pandemic might be imminent. ${ }^{10}$ With each PHEIC, the WHO advises governments on how to deal with the emergency.

Most importantly, on January 30, 2020, the WHO Director-General Tedros Adhanom Ghebreyesus stressed that, 'It is still possible to interrupt the virus spread, provided that countries put in place strong measures to detect the disease early, isolate and treat cases, trace contacts and promote social-distancing measures'. But governments around the world chose to ignore this piece of vital advice from the WHO and looking back the human cost of this ignorance has been horrendous and incalculable.

On March 28, 2020, Richard Horton, editor of the well-known medical journal Lancet criticised the UK government for its failure to heed the advice of the WHO writing, 'The scale of anger and frustration is unprecedented, and COVID-19 is the cause. The UK Government's Contain-Delay-Mitigate-Research strategy failed. It failed, in part, because Ministers did not follow the WHO's advice to 'test, test, test' every suspected case. They did not isolate or quarantine. They did not contact trace. These basic principles of public health and infectious disease control were ignored, for reasons that remain opaque.'

In the USA, the government failed to roll out testing nationwide until late February and it only banned some travel from China. There was a similar approach by many nations outside of China. By mid-March, the virus had spread around the world.

\footnotetext{
${ }^{10}$ World Health Organization News (2020).
} 
As an example of best practices, China's response to novel infectious diseases like COVID-19 shows that no matter how infectious and vicious, they can be effectively controlled-even in the absence of pharmaceutical solutions. Had the USA been equally decisive and successful, it could have saved more than 500,000 lives (Fig. 1).

Some segments of the human community have proven to be powerful leaders in confronting this global public health crisis of COVID-19 head-on and are sharing important lessons learned. It is deeply unfortunate that others turned out to be powerful saboteurs; they became spreaders of a social virus that spread misinformation, discrimination and dirty politics. ${ }^{11}$ The result was that powerful destructive human forces were unleashed, the opportunity costs of which can be measured by the excessive and avoidable human loss and serious socioeconomic setbacks for all of mankind.

Any open-minded analysis and serious reflection on global responses to COVID19 draw these vital conclusions. In order for the world to stand a better chance of preventing the next public health emergency, such as a new pandemic, all nations must learn how to work together and in the most effective manner. This must include important issues such as reforms of international health regulations and the structure of international organisations. That means we must learn how to strengthen (not weaken) multilateral mechanisms such as the UN and the WHO. Of course, any new cooperative spirit must be built on the keen recognition that we are really in this together. That realisation must be extended to how mankind interacts with the natural world on this planet, which is our shared home.

The evolution of the Earth is divided by geologists according to marked shifts in the state of the planet. Recent global environmental changes suggest that Earth may have entered a new human-dominated geological epoch, known as the Anthropocene Epoch. Since the 1950s the influence of human activity on the Earth system has increased markedly. This period of 'great acceleration' is marked by a major expansion in the impact of mankind on the planet. For example, the human population in 1950 was 2.5 billion, but by 2020 that figure had more than tripled to 7.7 billion. In that same time period, there have been large changes in natural processes, the development of new materials from minerals to plastics to persistent organic pollutants and inorganic compounds. It is little wonder that the impact of humans on the Earth has been the catalyst for global climate change. ${ }^{12}$

An increasing body of literature points out that as the Arctic warms, 'zombie' viruses and microbes are rising from the thawing ground. The frozen earth that covers much of the Arctic is home to growing microbial communities. For centuries, they have lain dormant, barely active or completely suspended, subsisting on minuscule pockets of water squeezed between the ice. With the Arctic warming at two to five times the global average, those pockets are becoming pools, rivulets, rivers, puddles and ponds. The Arctic is waking up, and the microscopic organisms embedded in the land might be coming back to life. ${ }^{13}$

\footnotetext{
${ }^{11}$ World Health Organization (2020).

${ }^{12}$ Nature (2015).

${ }^{13}$ The Narwhal (2020).
} 
These trends are just one example of why there is an urgent need for global collaboration to embrace evidence-based etiological modelling of novel infectious diseases. In turn, this would have important implications for expanding our horizons in our global effort for better predicting, preventing and controlling epidemics in the future. Moreover, adopting the Anthropocene perspective may help break the pernicious cycle that asserts that humans are just passive observers of Earth's functioning.

To a large extent, the future of the only place where life is known to exist is being determined by the actions of humans. Global public health security depends on wellcoordinated global actions. Divided, we are vulnerable. United, we are powerful and hopeful.

\section{References}

Bloom DE, Cadarette D (2019) Infectious disease threats in the 21st century: strengthening the global response. Front Immunol 10:549

GDP per capita (current US\$) (n.d.) Data. https://data.worldbank.org/indicator/NY.GDP.PCAP.CD. Accessed 18 Mar 2021

Gov. Cuomo: Feds need to consider 'rolling deployment' focused on NY first (2020), March 26. https://shelterislandreporter.timesreview.com/2020/03/26/gov-cuomo-feds-need-toconsider-rolling-deployment-focused-on-ny-first/. Accessed 18 Mar 2021

Liveright (2012) The social conquest of earth. Accessed 18 Mar 2021

Nature (2015) Defining the Anthropocene, March 11. https://www.nature.com/articles/nature14258. Accessed 18 Mar 2021

The Narwhal (2020) Will the next great pandemic come from the permafrost?, Apr 10. https://the narwhal.ca/next-great-pandemic-permafrost/. Accessed 18 Mar 2021

United Nations Population Division (n.d.) Department of Economic and Social Affairs https://www. un.org/en/development/desa/population/publications/database/index.asp. Accessed 18 Mar 2021

WHO Coronavirus (COVID-19) Dashboard (n.d.) https://covid19.who.int. Accessed 18 Mar 2021

World Affairs (1933) Inaugural address, March 4. http://www.jstor.org/stable/20662229. Accessed 18 Mar 2021

World Health Organization (2020) Report of the WHO China joint mission on coronavirus disease 2019 (COVID-19), 16-24 February. https://www.who.int/docs/default-source/coronavir use/who-china-joint-mission-on-covid-19-final-report.pdf. Accessed 18 Mar 2021

World Health Organization News (2020) Statement on the second meeting of the International Health Regulations (2005) Emergency Committee regarding the outbreak of novel coronavirus (2019-nCoV), January 30. https://www.who.int/news/item/30-01-2020-statement-on-the-sec ond-meeting-of-the-international-health-regulations-(2005)-emergency-committee-regardingthe-outbreak-of-novel-coronavirus-(2019-ncov). Accessed 18 Mar 2021

Yuanli Liu is Professor and Founding Dean of the School of Health Policy and Management at Peking Union Medical College. From 2013 to 2020, Dr. Liu served as founding Dean of the School of Public Health at the Chinese Academy of Medical Sciences \& Peking Union Medical College. Dr. Liu has been closely involved in China's major healthcare reforms and development initiatives as an applied health policy researcher since 1993. He currently also serves as a member of the State Councilor' Office, the State Council Healthcare Reform Expert Committee. $\mathrm{He}$ is also President of the Chinese Aging Well Association, Vice Chairman of the National 
Commission on Health Promotion and Education. From 1993 to 2013, Dr. Liu worked at Harvard University in the area of global health. He has consulted for many international organisations including the WHO, the World Bank and Fortune 500 companies.

Open Access This chapter is licensed under the terms of the Creative Commons AttributionNonCommercial-NoDerivatives 4.0 International License (http://creativecommons.org/licenses/bync-nd/4.0/), which permits any noncommercial use, sharing, distribution and reproduction in any medium or format, as long as you give appropriate credit to the original author(s) and the source, provide a link to the Creative Commons license and indicate if you modified the licensed material. You do not have permission under this license to share adapted material derived from this chapter or parts of it.

The images or other third party material in this chapter are included in the chapter's Creative Commons license, unless indicated otherwise in a credit line to the material. If material is not included in the chapter's Creative Commons license and your intended use is not permitted by statutory regulation or exceeds the permitted use, you will need to obtain permission directly from the copyright holder.

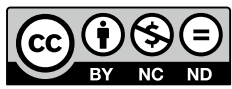

